\title{
Low-Flow Characteristics of Alabama Streams
}

GEOLOGTAL SURVEY WATER-SUPPLY PAPER 2083

Prepared in cooperation with the Genlogical Survey of Alabama

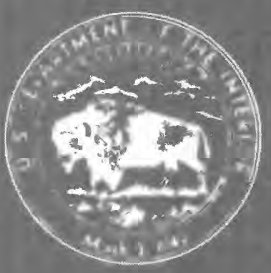




\section{Low-Flow Characteristics of Alabama Streams}

By R. H. BINGHAM

GEOLOGICAL SURVEY WATER-SUPPLY PAPER 2083

Prepared in cooperation with the

Geological Survey of Alabama

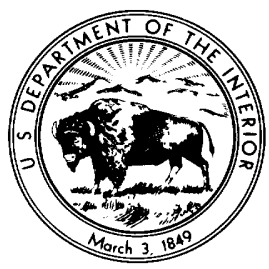




\title{
UNITED STATES DEPARTMENT OF THE INTERIOR
}

\author{
JAMES G. WATT, Secretary
}

GEOLOGICAL SURVEY

Dallas L. Peck, Director

Library of Congress Cataloging in Publication Data

Bingham, Roy H., 1930-

Low-flow characteristics of Alabama streams.

(Geological Survey Water-Supply Paper 2083)

Bibliography: p. 20

Supt. of Docs. No.: I 19.13:2083

1. Stream measurements-Alabama.

I. Alabama Geological Survey. II. Title. III. Series: United States Geological Survey Water-Supply Paper 2083

GB1225 A2B56

1981

$551.48^{\prime} 3^{\prime} 09761$

$80-607849$

AACR2

For sale by the Branch of Distribution, U.S. Geological Survey, 604 South Pickett Street, Alexandria, VA 22304 


\section{CONTENTS}

\begin{tabular}{|c|c|}
\hline & Page \\
\hline 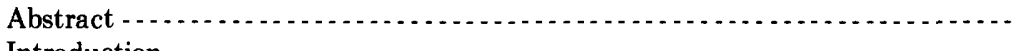 & 1 \\
\hline Introduction & 1 \\
\hline Units of measurements & 2 \\
\hline Application of estimating methods & 3 \\
\hline Ungaged sites & 4 \\
\hline Limitations and accuracy & 6 \\
\hline Analytical techniques & 8 \\
\hline mflow recession & 9 \\
\hline ontributions to streamflow $-\ldots \ldots \ldots \ldots \ldots$ & 11 \\
\hline mflow-recession indexes & 14 \\
\hline Regression analyses $-\ldots$ & 16 \\
\hline n & 20 \\
\hline eferences cited 1. & 20 \\
\hline 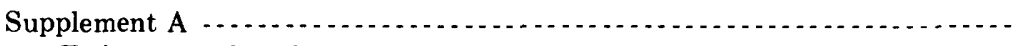 & 22 \\
\hline Estimates of low flow for ungaged sites & 22 \\
\hline upplement B & 25 \\
\hline
\end{tabular}

\section{ILLUSTRATIONS}

Plate 1. Map of Alabama showing streamflow recession indexes and boundaries, gaging station locations, and areas where 7-day, 2-year low flow is less than 0.3 cubic foot per second and 7-day, 10-year low flow is less than 0.1 cubic foot per second .......... In pocket

2. Generalized geologic map of Alabama -................... In pocket

FigURE 1. Map of Alabama showing mean annual precipitation

2. Graphical solution of $7 Q_{2}$ low-flow equation-........ 6

3. Graphical solution of $7 Q_{10}$ low-flow equation ............ 7

4. Generalized cross section of a stream basin showing ground-water

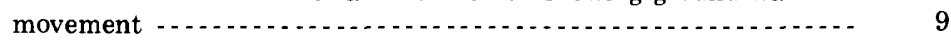

5. Graph showing streamflow recessions for Shoal Creek near Iron City, Tenn. . . .

6. Graph showing streamflow recessions for Sipsey River near Fayette, Ala. . . . . . . . . . . .

7. Graph showing streamflow recessions for Fish River near Silverhill,

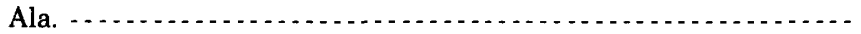

8. Generalized sketch of Fish River basin and aquifer boundaries, near

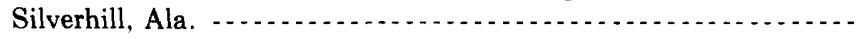




\title{
LOW-FLOW CHARACTERISTICS OF ALABAMA STREAMS
}

\author{
By R. H. BINGHAN
}

\begin{abstract}
A new procedure for estimating the 7-day, 2-year and the 7-day, 10-year low flow of ungaged Alabama streams is based on geology, drainage area, and mean annual precipitation. One equation for each of the two low-flow frequencies applies statewide to all natural flow streams; the equations do not apply to streams where flow is significantly altered by activities of man. The standard error of estimate of each equation based on map values is 40 percent for 7-day, 2-year low flow and 44 percent for 7-day, 10-year low flow.

The rate of streamflow recession is used to account for the effects of geology on low flow. Streamflow recession rate depends primarily on transmissivity and storage characteristics of the aquifers, and average distance from stream channels to divides. Relations of low-flow discharge to geology, drainage area, and mean annual precipitation were analyzed by multiple regression techniques.
\end{abstract}

\section{INTRODUCTION}

Optimum development of surface-water resources depends on the rate of sustained streamflow during dry periods. In Alabama, a dry period generally occurs during October and November of each year. Perhaps the most significant use of estimates of low flow are by State and local government agencies for determining the permissible rate of waste disposal into a given stream.

In response to increasing needs for low-flow information, the U.S. Geological Survey began, in cooperation with the Geological Survey of Alabama, a study in 1975 to estimate low flow of streams in Alabama. The study was divided into two phases. During the first phase, statistical analyses of daily streamflow data for continuous record gaging stations were performed to derive estimates of low-flow discharge for selected frequencies, and duration of streamflow. Low-flow characteristics for continuous gaging stations with less than 10 years of record were estimated by correlation with continuous gaging stations with more than 10 years of record. Estimates of low-flow characteristics for continuous gaging stations were used to estimate low flow at partialrecord stations by methods of correlation. Results of the first phase of the study are presented in a report by Hayes (1978). 
During the second phase of the study, new methods were developed to estimate two low-flow characteristics of Alabama streams-the 7-day, 2-year $\left(7 Q_{2}\right)$ and the 7-day, 10-year $\left(7 Q_{10}\right)$ low flow. The $7 Q_{2}$ and $7 Q_{10}$ are the discharges at 2-year and 10-year recurrence intervals taken from a frequency curve of annual values of the lowest mean discharge for 7 consecutive days. The new methods consist of modeling regional relations that are based on the most significant factors that control or influence low flow. Regression equations were derived from low-flow data at gaging stations in combination with a base flow recession index, drainage area, and mean annual precipitation. The equation for each of the two low-flow frequencies applies statewide.

Many attempts have been made to regionalize low-flow characteristics by multiple regression with basin and climatic characteristics. Those attempts generally produced unacceptable results because standard errors were too large to apply equations regionally to ungaged streams. One of the better regressions, which was derived for Connecticut, related $7 Q_{10}$ low flow to drainage area, mean basin elevation, and percentage of the basin underlain by stratified drift; the equation has a standard error of 68 percent (Thomas and Cervione, 1970).

Three previous reports describe the $7 Q_{2}$ and $7 Q_{10}$ low flow, and flow duration of Alabama streams: Peirce (1959), Peirce (1967), and Hayes (1978). The report by Hayes is based on streamflow data through 1973 and provides a better estimate of $7 Q_{2}$ and $7 Q_{10}$ low flow, and flow duration of streams in Alabama.

This report is based on low-flow data collected as part of cooperative programs with the Geological Survey of Alabama and other State and Federal agencies. Low-flow data for some streams in the Tennessee River basin were furnished by the Tennessee Valley Authority.

\section{UNITS OF MEASUREMENTS}

Analyses and compilations used in this report are in inch-pound units of measurements. Factors for converting inch-pound units to metric units are listed below.

\begin{tabular}{lcll}
\multicolumn{1}{c}{ Inch-pound } & $\begin{array}{c}\text { Conversion } \\
\text { factor }\end{array}$ & & \multicolumn{1}{c}{ Metric units } \\
inch $(\mathrm{in})$ & 25.4 & & millimeter $(\mathrm{mm})$ \\
mile $(\mathrm{mi})$ & 1.609 & & kilometer $(\mathrm{km})$ \\
square mile $\left(\mathrm{mi}^{2}\right)$ & 2.59 & & square kilometer $\left(\mathrm{km}^{2}\right)$ \\
cubic foot per second $\left(\mathrm{ft}^{3} / \mathrm{s}\right)$ & 0.0283 & & $\begin{array}{l}\text { cubic meter per second } \\
\left(\mathrm{m}^{3} / \mathrm{s}\right)\end{array}$
\end{tabular}

Multiply inch-pound units by the conversion factor to obtain metric units. 


\section{APPLICATION OF ESTIMATING METHODS}

The estimating methods consist of regression equations using a base flow recession index, drainage area, and mean annual precipitation. Detailed discussion of data analyses and procedures used to derive the estimating methods are given in subsequent sections of this report. These methods can be used to estimate low flow in streams with drainage areas of 5 to $2,460 \mathrm{mi}^{2}$. However, these methods should not be used on streams where the low flow is significantly altered by activities of man, nor streams where the $7 Q_{2}$ low flow is less than $0.3 \mathrm{ft}^{3} / \mathrm{s}$ and the $7 Q_{10}$ low flow is less than $0.1 \mathrm{ft}^{3} / \mathrm{s}$.

$\begin{array}{cc}7 Q_{2}=0.24 \times 10^{-4}(G-30)^{1.07}(A)^{0.94}(P-30)^{1.51} & \begin{array}{c}\text { Standard error } \\ \text { of estimate, } \\ \text { percent }\end{array} \\ { }=0.15 \times 10^{-5}(G-30)^{1.35}(A)^{1.05}(P-30)^{1.64} } & 38 \\ & 39\end{array}$

where $7 Q_{2}=$ estimated $7 Q_{2}$ low flow, in cubic feet per second,

$7 Q_{10}=$ estimated $7 Q_{10}$ low flow, in cubic feet per second, $G=$ streamflow recession index, in days per log cycle of discharge depletion, $A=$ contributing drainage area, in square miles, and $P=$ mean annual precipitation, in inches.

All regression coefficients are statistically significant at the 5-percent level.

Accuracy of the regression equations is expressed as standard error of estimate in percent. Standard error is computed from the difference between station data and the regression equation. Standard error of estimate is the range of error to be expected about two-thirds of the time. The standard error of estimate listed above is based on regression analyses using a base-flow recession index for each station used in the analyses. A more representative standard error is the error based on discharge computed using recession indexes determined from plate 1 in regression equations for $7 Q_{2}$ and $7 Q_{10}$. Residuals in log units were determined from the difference in the discharge estimated with regression equations and the discharge estimated from continuous streamflow records. The residuals for gaging stations were used to determine the error of estimate with map values of recession indexes.

The equation is

$$
S E=\sqrt{\frac{R^{2}}{N-M}}
$$


where $S E=$ standard error of estimate,

$R=$ station residual,

$N=$ number of stations in the analyses, and

$M=$ number of variables in the analyses.

The standard error of the regression using the mapped index of base flow recession is 40 percent for $7 Q_{2}$ and 44 percent for $7 Q_{10}$.

Values for variables used in the equations can generally be estimated from maps. Drainage area can be measured from topographic maps; streamflow-recession index can be determined from plate 1; and mean annual precipitation can be estimated from figure 1 .

\section{UNGAGED SITES}

The following procedures can be used to estimate the $7 Q_{2}$ and $7 Q_{10}$ low flow for ungaged sites on natural-flow streams in Alabama. From topographic maps, determine the drainage area upstream from the site. From plate 1, determine the streamflow-recession index for the stream basin. From figure 1 estimate the mean annual precipitation for the site. The $7 Q_{2}$ and $7 Q_{10}$ low flow for the site is estimated by substituting the values of drainage area, streamflow-recession index, and mean annual precipitation into the regression equations and performing the indicated mathematical operation. Examples using the regression equations to estimate low flow in ungaged streams are given in Supplement A of this report.

The estimating procedures are modified for a stream basin draining two or more areas of different streamflow-recession indexes. Drainage area and mean annual precipitation are estimated as described in the preceding paragraph. However, discharge from each of the two or more streamflow-recession index areas must be computed separately using the equations and the results weighted based on an estimate of the percent of the basin draining each streamflow-recession index area. Use of the regression equations for estimating low flow of ungaged streams draining areas having two streamflow-recession indexes and draining areas having three streamflow-recession indexes are described in Supplement A.

Solutions for the preceding equations for estimating $7 Q_{2}$ and $7 Q_{10}$ low flows are presented in graphical form as shown in figures 2 and 3 , respectively. The dashed line and arrows on the figures indicate the procedure to follow in the following example:

$$
\begin{aligned}
& A=120 \mathrm{mi}^{2} \\
& \mathrm{G}=50 \\
& \mathrm{P}=52 \mathrm{in} .
\end{aligned}
$$




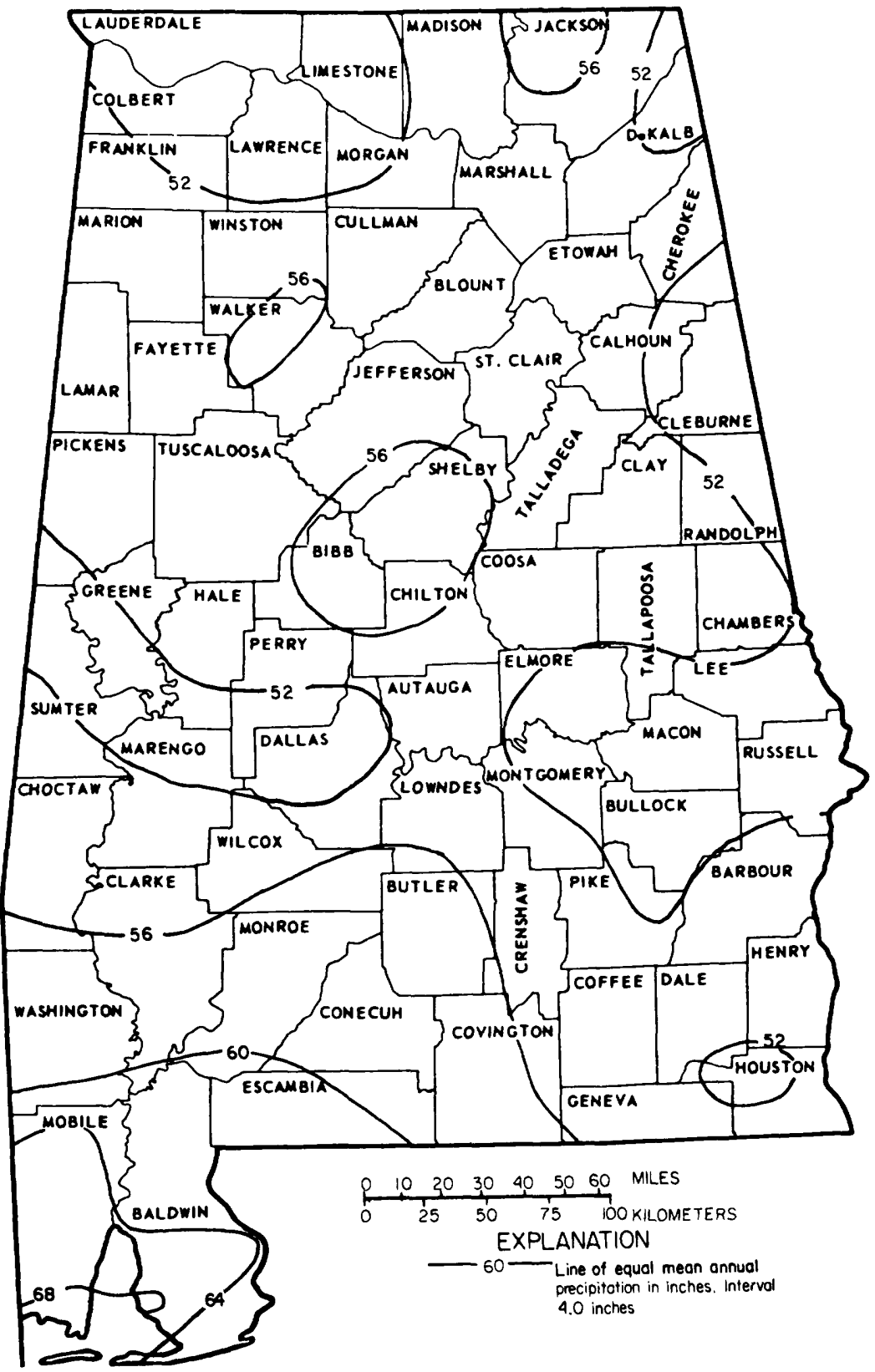

From National Oceonic and Atmospheric Administration.

Bosed on period 1931-1955 with interim revisions bosed on period 1931.1960; reviewed by National Weather Service. Doto does nat necessorily ogree with Climatic Atlos of the U.S., 1968.

FiguRE 1.--Mean annual precipitation for Alabama. 


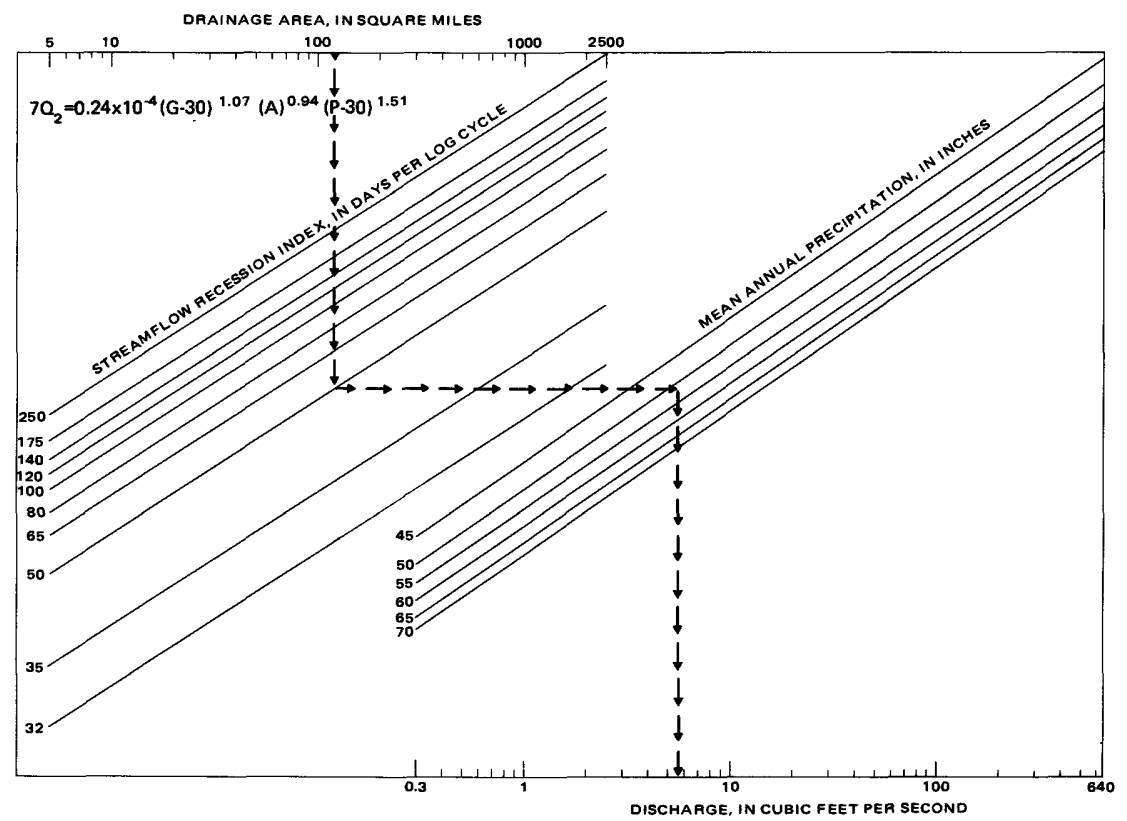

FigURE 2.-Graphical solution of $7 Q_{2}$ low-flow equation.

Enter the figures with drainage area $\left(120 \mathrm{mi}^{2}\right)$ along the top scale. Move downward to streamflow-recession index graphs to 50 . Move horizontally to precipitation graphs to 52 in. Move downward to discharge scale. The following results were obtained for this example:

from figure $2,7 Q_{2}=5.7 \mathrm{ft}^{3} / \mathrm{s}$.

from figure $3,7 Q_{10}=2.1 \mathrm{ft}^{3} / \mathrm{s}$.

Limitations on the use of the graphs for estimating low flows are described in another section of this report. For an example of estimating low flow in streams draining two or more areas with different streamflow-recession indexes refer to Supplement A.

\section{LIMITATIONS AND ACCURACY}

The regression equations in this report are limited to estimating the $7 Q_{2}$ and $7 Q_{10}$ low flow in natural flow streams in Alabama. In deriving the equations, drainage areas ranged from 5.1 to $2,460 \mathrm{mi}^{2}$, mean annual precipitation ranged from 49 to $68 \mathrm{in}$., and streamflow-recession indexes ranged from 32 to 250 for $7 Q_{2}$ and from 35 to 250 for $7 Q_{10}$. Low-flow discharges ranged from 0.3 to $640 \mathrm{ft}^{3} / \mathrm{s}$ for $7 Q_{2}$ and from 0.1 to $250 \mathrm{ft}^{3} / \mathrm{s}$ for $7 Q_{10}$.

Use of the equations should be limited to the range in low-flow discharge, drainage area, streamflow-recession indexes, and mean annual 
precipitation used to derive the equations. Equation estimates of low flow less than $0.3 \mathrm{ft}^{3} / \mathrm{s}$ for $7 Q_{2}$ and less than $0.1 \mathrm{ft}^{3} / \mathrm{s}$ for $7 Q_{10}$ should be considered as zero. Plate 1 shows areas where the low flow is less than $0.3 \mathrm{ft}^{3} / \mathrm{s}$ for $7 Q_{2}$ and less than $0.1 \mathrm{ft}^{3} / \mathrm{s}$ for $7 Q_{10}$.

The regression equations should not be used on streams where the flow is significantly affected by regulation or other activities of man. Caution should be used when applying the equations to streams where a significant amount of the low flow is contributed by springs. Definition of the contributing drainage area, in such cases, is uncertain. Caution also should be used in applying the equations to streams where the basin is underlain primarily with limestone. Solution cavities in the limestone may alter the rate of low flow considerably within short reaches of the stream.

Standard error of the regression equations based on map values of base-flow recessions are 40 percent for $7 Q_{2}$ and 44 percent for $7 Q_{10}$. Those errors apply only to the continuous record gaging stations used in the regression analyses. The errors associated with use of the equations to estimate low flows in ungaged streams are unknown.

The equations were used to estimate $7 Q_{2}$ and $7 Q_{10}$ for partial-record stations and the results compared with estimates obtained from correlation methods. The stations selected were assumed to represent

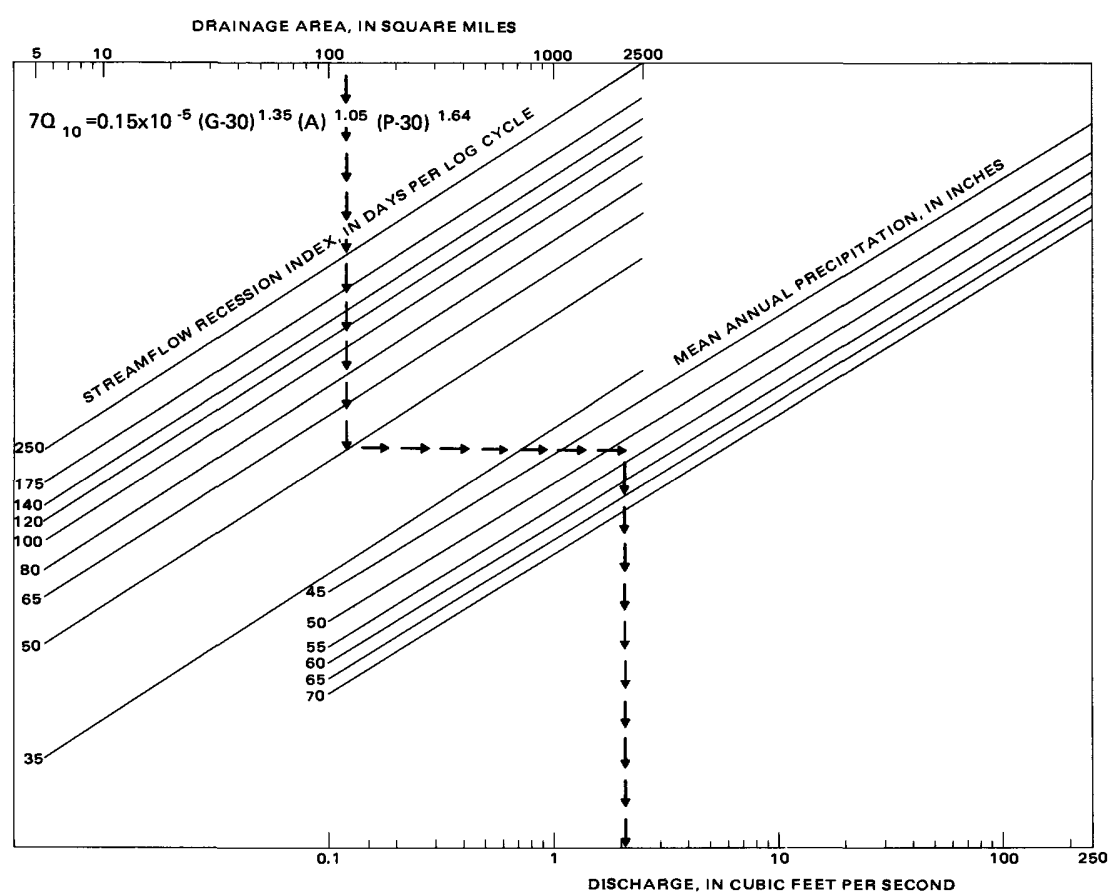

FIGURE 3.-Graphical solution of $7 Q_{10}$ low-flow equation. 
natural flow. Streamflow recession index used in the equations was determined from plate 1, mean annual precipitation from figure 1, and drainage area from topographic maps.

Percent difference in estimates obtained from the two methods was related to the standard error of estimate of the regression equations. Differences in the results for 65 percent of the partial-record stations were within the 40 percent standard error of estimate for $7 Q_{2}$, and 64 percent of the stations were within 44 percent standard error of estimate for $7 Q_{10}$. Although this comparison between results obtained from equations and results obtained from correlation is not completely independent, it does indicate confidence in the equations.

\section{ANALYTICAL TECHNIQUES}

Analyses of the factors that influence the rate of low flow were performed to regionalize methods of estimating low flow on a statewide basis. The most significant result of these analyses is to systematically relate the effects of geology to the rate of low flow. The relationship is defined by streamflow recession rates for various rock types and combination of rock types. Streamflow-recession rates are influenced by acquifers within the geologic framework underlying the basin. Thus, the streamflow-recession rates or indexes used in these analyses reflect the effect of geology. The area boundaries were delineated based on geologic maps.

Low flow in a stream is usually ground water discharged from the aquifer system to the stream. A generalized cross section of a stream basin illustrating the movement of ground water from the aquifer system to the stream is shown in figure 4 . The rate of ground-water discharge to a stream is a function of the capacity of the aquifer to store and transmit water, aquifer thickness and areal extent, slope of the water level within the aquifer, amount of precipitation to recharge the aquifer, the size of the stream basin, and time. The interaction between the hydraulic characteristics of the aquifer or groups of aquifers and low flow is extremely complex. Most streams used in these analyses receive water from two or more aquifers each having different effects on the low flow of the streams. Areal differences occur in the aquifer characteristics within a given rock type or from one rock type to another type.

Rorabaugh and others (1966) investigated methods of relating ground water to surface water in the Columbia River basin. In their work, ground-water discharge to selected streams was related to the physical characteristics of the aquifer system as evidenced by the recession pattern of the water level in the aquifer system during a period of no recharge. The authors state on page 36 of their open-file report; "Under 


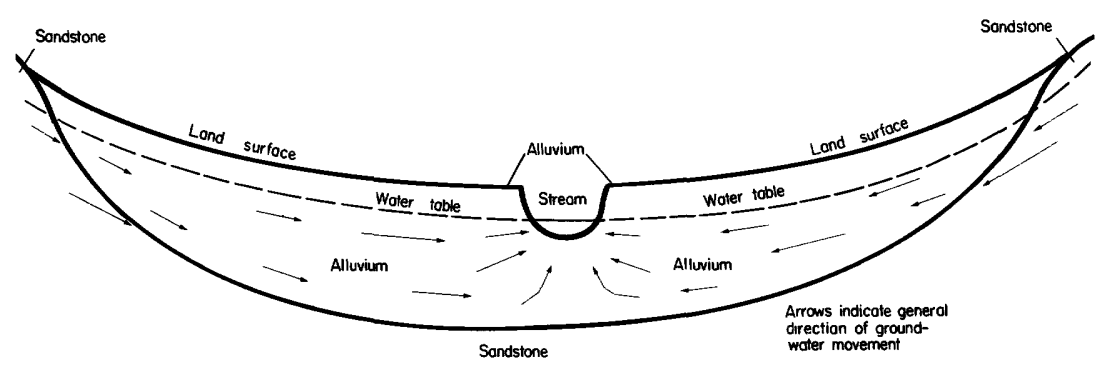

FIGURE 4.-Generalized cross section of a stream basin showing ground-water movement.

long-term conditions of ground-water depletion there should be a definite relation between the water level in a well and ground-water discharge at that time. Inasmuch as water levels and ground-water outflow are directly related and either depletion or gain in ground-water storage are dependent on the same variables, there is little reason to expect under ideal conditions that water levels would be any better than low streamflows as an index for projection into the future." The report (Rorabaugh and others, 1966) also indicates that base-flow recession for continuous-record gaging stations on unregulated streams can be used to forecast flow characteristics.

Rorabaugh and others described the hydraulic principles used to estimate low flow based on water-level recession in wells. For this report, however, the base-flow recession is used to estimate low flow; waterlevel recession in wells was not considered.

\section{STREAMFLOW RECESSION}

The rate of streamflow recession during base flow is controlled by the hydraulic characteristics of the aquifers. The streamflow-recession index can be estimated by the equation (Rorabaugh and others, 1966):

$$
t=\frac{a^{2} S}{T},
$$

where $t=$ time in days per log cycle,

$a=$ distance from the stream to the hydrologic divide,

$S=$ storage coefficient of the aquifer or aquifers, and

$T=$ transmissivity of the aquifer or aquifers.

For this report, values of the hydraulic characteristics are not necessary as discharge data were used to estimate the streamflow-recession indexes graphically. However, according to Trainer and Watkins, (1974, p. 126-127) factors which affect the streamflow-recession index complicate its interpretation. They briefly describe three factors which include: (1) The brevity of most recession events makes it difficult to 
determine precisely the index of the streamflow recession, (2) evapotranspiration of ground water and streamflow distort the recession during much of the year, and (3) complexity of many recessions may be influenced by nonhomogeneity of the aquifers or the presence of multiple aquifers.

Records from approximately 200 continuous-gaging stations were examined to define the streamflow-recession indexes to use in the equations for estimating low flow in Alabama streams. Streamflow-recession indexes were defined for 127 of those sites; streamflow at the remaining stations was regulated or significantly affected by other activities of man, or the record was too short to define the streamflow-recession indexes. The streamflow recession was plotted on semilog graph paper, discharge on the log scale, and time, in days, on the arithmetic scale. Figure 5 illustrates the streamflow recession for Shoal Creek. Several recessions were plotted for each station to assure consistency in the recession index definition. The index of streamflow recession was defined in days per log cycle, that is, the number of days required for discharge to decline one complete log cycle.

Streamflow records for periods during November through February were generally used for defining the streamflow-recession indexes. During that time, interferences from evaporation and transpiration are least, and consistent definitions of streamflow recessions were obtained for each gaging station.

The peak discharge during a period of rainfall is used as the first plotting point for the streamflow-recession curve. The plotting of stream discharge for each successive day is continued until the streamflowrecession curve becomes apparently straight. The time required for the straight-line condition is a function of the basin geometry and the properties of the basin material (Rorabaugh and others, 1966). The straight-line part of the curve is used to define the index of streamflow recession.

Definition of the streamflow-recession index, for numerous stations, can be aided or verified by a critical-time factor. The critical-time factor is explained by Rorabaugh and others (1966). After the days per log cycle have been estimated from the recession plot, multiply the number of days by the critical-time factor (0.2) to determine the length of time required for the recession curve to become an apparent straight line. The critical-time procedure works fairly well when the first plotting point on the recession curve represents medium to high discharge. For low to medium discharge, the curves represent increments or additions to the composite of all past events, and, in many cases, the critical time factor may be as low as 0.1 and may not be conclusive (Daniel, 1976). In many stream basins in Alabama, the geometry and aquifer characteristics are such that the critical time may represent weeks or months. 


\section{MULTIPLE AQUIFER CONTRIBUTIONS TO STREAMFLOW}

On a Statewide basis the variation of aquifer characteristics and interaction of aquifers and streamflow is extremely complex. In many streams the flow represents the effects of several aquifers, each having different characteristics. The streamflow-recession indexes for most of those streams represent naturally integrated effects of the different aquifers within the basin (Daniel, 1976). For example, flow of Sipsey River near Fayette, in Fayette County (pl. 1) represents naturally integrated effects of both aquifers. Streamflow recessions for Sipsey River near Fayette are shown in figure 6.

\section{Shoal Creek at Iron City, Tennessee Station 03588500 ( 1 aquifer)

$$
\text { Area }=348 \mathrm{mi}^{2}
$$

Recession index $=140$ days per log cycle

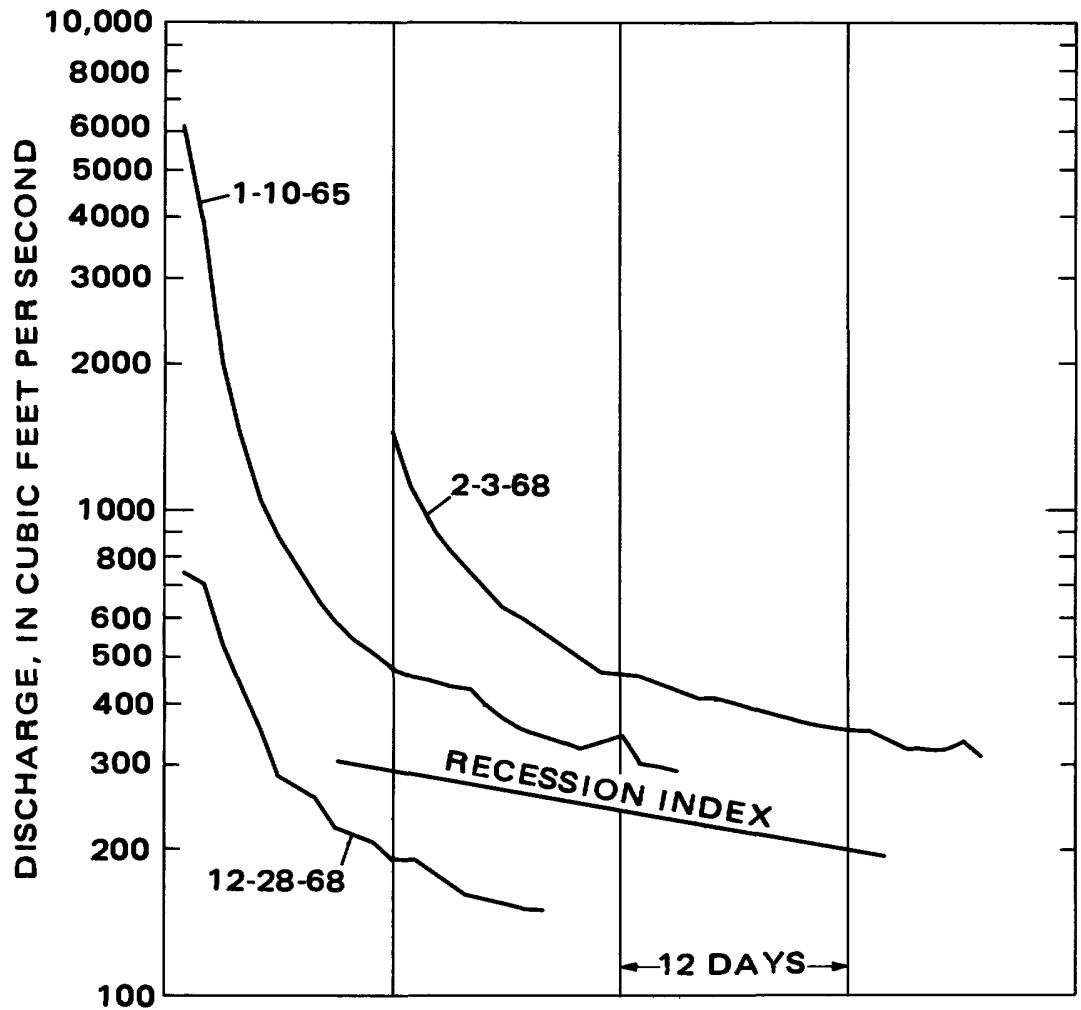

TIME, IN DAYS

FiguRE 5.-Streamflow recession for Shoal Creek near Iron City, Tenn. 
Sipsey River near Fayette, Alabama Station 02445500 (2 aquifers, 140 and 35) Area $=276 \mathrm{mi}^{2}$

Recession index $=66$ days per log cycle

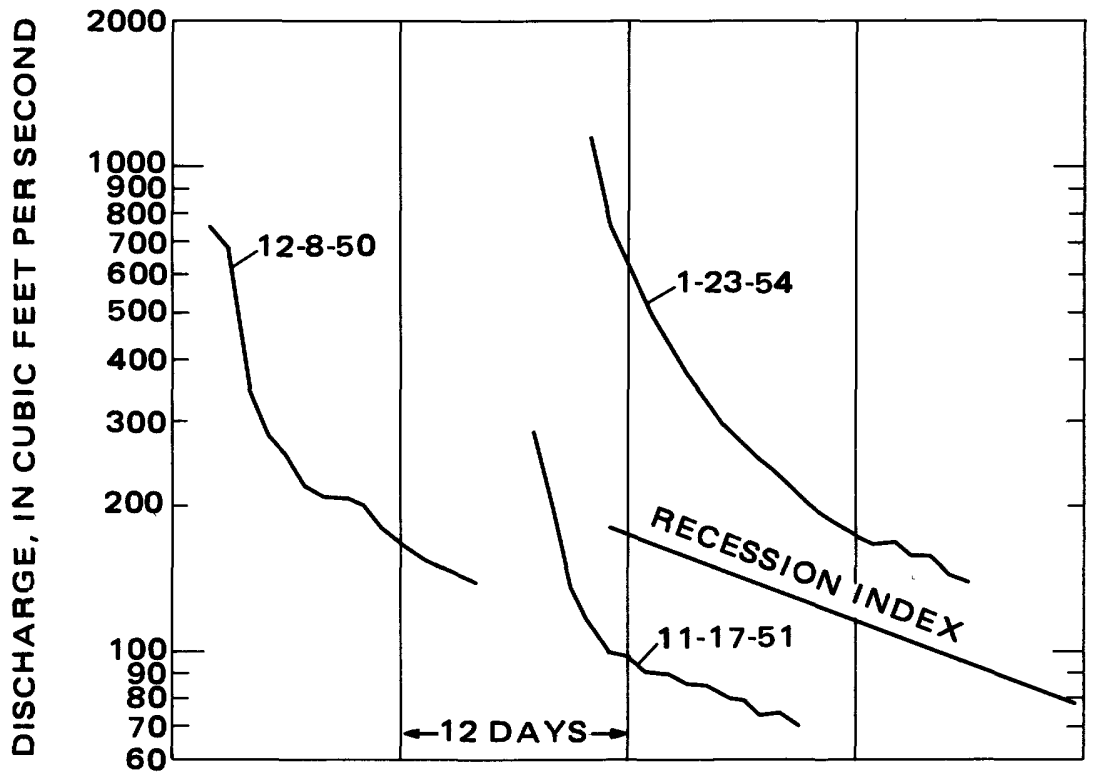

TIME,IN DAYS

FigURE 6.-Streamflow recessions for Sipsey River near Fayette, Ala.

For several streams used in this analysis, the streamflow recessions represent, by separate straight-line segments, the effects of different aquifers. Riggs (1964, p. 353-354) describes how runoff from two very unlike aquifers in the same drainage basin might produce two very distinct regions or straight-line segments in the recession index. When two significantly different indexes are observed, it seems reasonable that the flatter one would control longer frequency low flows. For example, an index of 50 days per log cycle would deplete 99.999 percent of a beginning discharge during the same period that an index of 250 days per log cycle would deplete only 90 percent of the same beginning discharge. Therefore, when both indexes are observed in a single basin, the resulting discharge is the sum of the contributions from each part of the drainage area and the separate effects are relatively easily distinguished. The streamflow recessions for Fish River near Silverhill, Baldwin County, illustrates two indexes representing two unlike aquifers (fig. 7). When two or more only slightly different indexes might 


\section{Fish River near Silverhill, Alabama Station 02378500 (2 aquifers)$$
\text { Area }=55.1 \mathrm{mi}^{2}
$$

\section{Recession index}

(sand and gravel aquifer $=\mathbf{2 5 0}$ days per log cycle

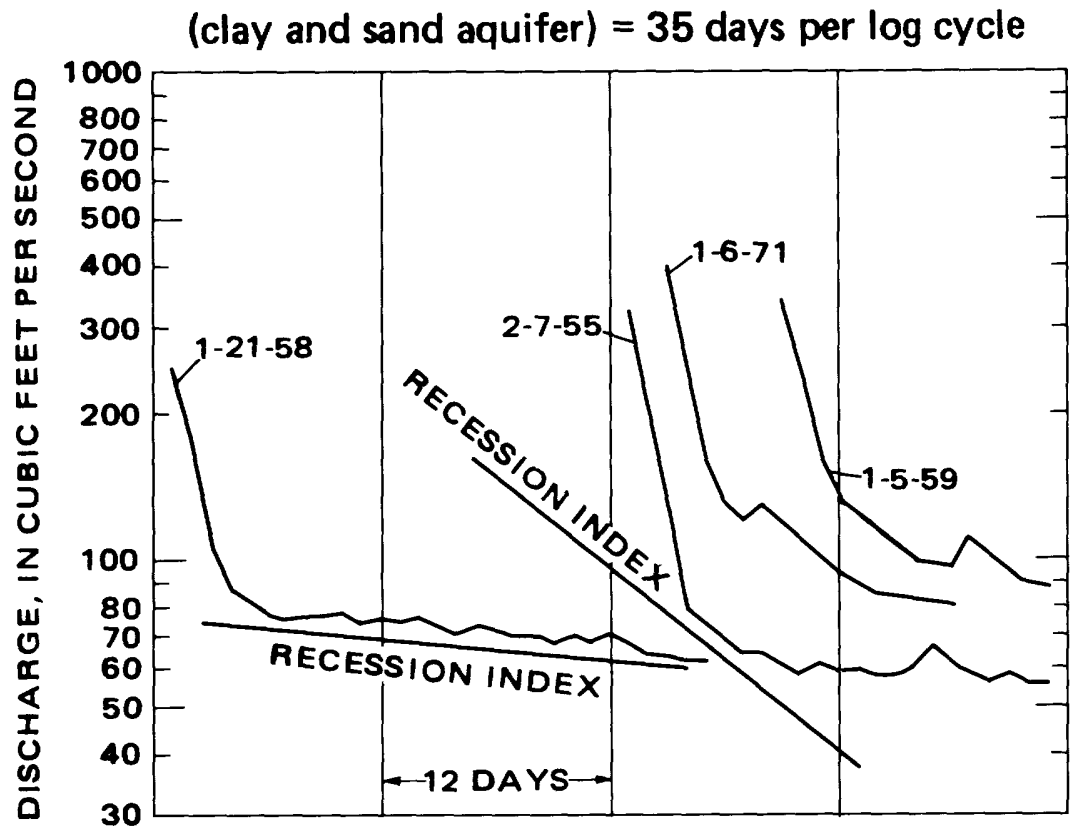

TIME, IN DAYS

FiguRE 7.-Streamflow recessions for Fish River near Silverhill, Ala.

be expected on the basis of geologic formations, a single observed index can be a naturally integrated effect, as explained previously. In that case, the separate effects from each part of the drainage area may be indistinguishable.

For the purposes of developing the regression equations, no simple method exists for assigning fractions of 7-day low flow to parts of a basin. In the case of naturally integrated recessions, such might not be possible while at the same time preserving the statistical integrity of the data. Therefore, an expedient weighting procedure was used as described below. For the purposes of application of the regressions, however, the effect of contributions from different parts of the basin can be accounted for by a procedure described in Supplement A. 
The weighted-average procedure was based on an estimate of the percentage of a stream basin draining each of two or more unlike aquifers. Fish River at station 02378500 near Silverhill in Baldwin County adjacent to Mobile Bay provides an example of the averaging procedure. A generalized sketch of Fish River basin is shown in figure 8 . The stream has cut through the entire thickness of the sand-and-gravel aquifer and the streambed and area adjacent to the stream is in the underlying clay and sand. The sand and gravel provide outflow which gives an extremely high base flow. Approximately 58 percent of the basin drains the sand and gravel aquifer which has a streamflowrecession index for Fish River of 250 days per log cycle and 42 percent of the basin drains the underlying clay-and-sand-aquifer which has a streamflow-recession index of 35 days per log cycle (fig. 7). The weighted-average streamflow-recession index is computed by summing 58 percent of 250 days per log cycle and 42 percent of 35 days per log cycle. Thus, weighted-average streamflow-recession index of the two aquifers is 145 plus 15 equals 160 days per log cycle for Fish River at station 02378500 . The weighted-average streamflow-recession index is the best estimate of the combined effects of two aquifers on low flow of Fish River at station 02378500 . A weighted average streamflow recession index was used for 14 stations in Alabama.

\section{MAPPING STREAMFLOW-RECESSION INDEXES}

Areas where streamflow recession indexes are similar were delineated based on streamflow records, geologic contacts, and lithology. The streamflow recession indexes defined for each of the 127 continuous gaging stations were used to represent the relative effects of geology on low flow. Geology and low-flow characteristics were evaluated by plotting gaging station locations and listing their respective streamflow recession indexes on a map of the State (pl. 1). The data in plate 1 were compared with that on a geologic map of the State to delineate areas where geologic effects on low flow are similar. The geologic map of the State has been revised in some areas primarily in the south half of the State. The map is currently in manuscript form at the same scale as plate 1 . The revised map is unavailable for inclusion in this report, however, a generalized geologic map is shown in plate 2. The stratigraphic nomenclature on the map is that of the Geological Survey of Alabama and does not necessarily follow the usage of the U.S. Geological Survey.

The State geologic map was inadequate in many areas to delineate boundaries of similar geologic effects on low flow. In those areas county maps were used to delineate the boundaries. For example, the boun- 


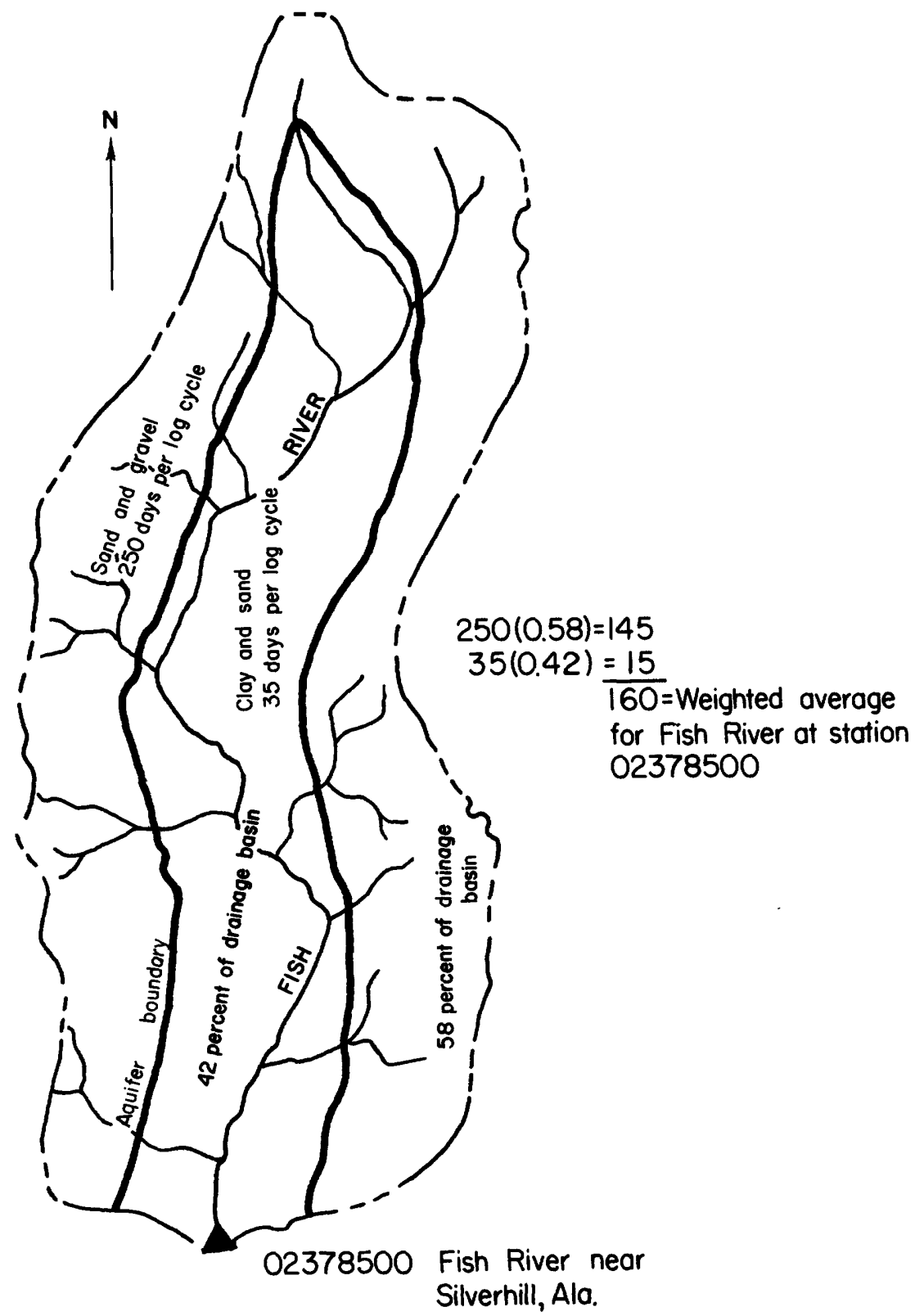

FIGURE 8.-Generalized sketch of Fish River basin and aquifer boundaries, near Silverhill, Ala. 
daries in Pickens County in west-central Alabama were based on a geologic map for Pickens County. The county map was used to delineate the two areas where streamflow-recession indexes are 35 and 100 days per log cycle. The two separate areas are not apparent on the State geologic map. The county maps provide better locations of geologic contacts and descriptions of lithology.

Adequate lithologic descriptions are essential in determining the position of streamflow-recession index boundaries. In many areas, several formations with similar lithology and water-bearing properties were grouped together in a single streamflow-recession index area (pl. 1). Boundaries between areas of different indexes on plate 1 follow the same general pattern of contacts between formations or groups of formations with major differences in lithology and water-bearing properties. For example, formations consisting primarily of clay, silt, or chalk are considerably different in water-bearing properties than formations consisting primarily of sand. Similarly, the water-bearing properties of sand and gravel differ considerably from limestone or shale. The large number of days per log cycle are generally associated with coarse sand and gravel or mixtures of those rock types. The small number of days per log cycle are generally associated with clay or chalk. The streamflow-recession indexes represent the relative capacity of the aquifers to release water to streams during low flow; large number of days per log cycle represent slower depletion and small number of days per log cycle represent faster depletion of water available for release.

Although lithology is one of the criteria used in delineating streamflow-recession index areas on plate 1 , local variations in lithology may result in indexes considerably different than the areas indicate. The local variations in lithology are probably more prevalent in the southern half of the State. The areas on plate 1 represent approximately average streamflow-recession indexes; the index may vary slightly from stream to stream within each area. The map is limited to 10 categories of index areas for practical application in estimating low flows. Perhaps 15 to 20 categories could be delineated, but the map would be cumbersome and difficult to use. The procedures used to delineate streamflowrecession index areas on plate 1 are highly subjective to interpretation of lithology, particularly in areas where streamflow data are inadequate to define the geologic effects on low flow.

\section{REGRESSION ANALYSES}

$7 Q_{2}$ and $7 Q_{10}$ low flows at gaging stations were related to various basin and climatic characteristics by using step-forward and stepbackward regression techniques. Low-flow data used in the regression analyses are tabulated in Supplement B. Characteristics tested were: streamflow-recession index, drainage area, main channel slope, length 
of main channel, mean basin elevation, percent forest cover within the basin, mean annual precipitation, and 24-hour, 2-year-recurrenceinterval rainfall. After several regression analyses were computed, another climatic characteristic was inserted into the regression in an attempt to lower the error of estimate. That characteristic was the normal number of days during July, August, and September with 0.5 inch or more of rainfall. The number of days ranged from 8 to 16 , and were distributed across the State in the same general pattern as the 24-hour, 2year rainfall intensity. Streamflow-recession index, drainage area, and mean annual precipitation were the only characteristics significant at the 5 percent level.

Drainage area for gaging stations used in the regression analyses ranged from 5.1 to $2,420 \mathrm{mi}^{2}$. However, the distribution of drainage areas varies considerably within that range. For example, only three stations have a drainage area greater than $1,000 \mathrm{mi}^{2}$, and only one station has a drainage area greater than $2,000 \mathrm{mi}^{2}$. The following table summarizes the distribution of drainage areas for stations used in the regression analyses.

\begin{tabular}{|c|c|c|c|}
\hline $\begin{array}{l}\text { Range in drainage } \\
\text { area } \\
\left(\mathrm{mi}^{2}\right)\end{array}$ & & \multicolumn{2}{|c|}{$\begin{array}{l}\text { Number of stations } \\
\text { in analyses }\end{array}$} \\
\hline $\begin{array}{c}5-25 \\
26-100 \\
101-250 \\
251-500 \\
501-1000 \\
1001-2000 \\
2001-2500\end{array}$ & & $\begin{array}{r}10 \\
21 \\
41 \\
26 \\
8 \\
2 \\
1\end{array}$ & $\begin{array}{c}7 \\
19 \\
36 \\
23 \\
8 \\
2 \\
1\end{array}$ \\
\hline & Total stations $\ldots$ & 109 & 96 \\
\hline
\end{tabular}

The recession indexes used in the regression analyses ranged from 32 to 200 . The following table summarizes distribution of streamflowrecession indexes for gaging stations used in the regression analyses.

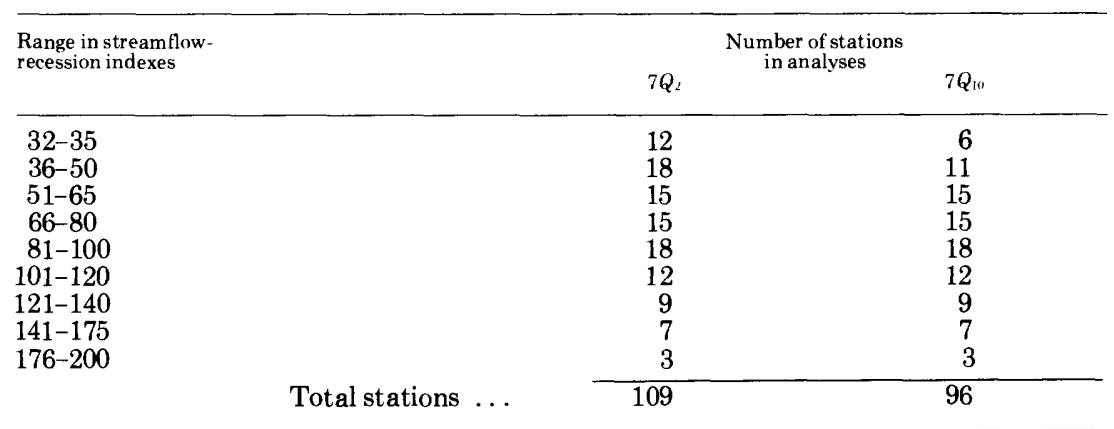


The mean annual precipitation for gaging stations used in the regression analyses ranged from 49 to 68 inches. For most stations, however, mean annual precipitation ranged from 52 to 56 inches. Precipitation is greatest in the extreme southwestern part of the State and least in the east-central part. The following table summarizes the distribution of mean annual precipitation for gaging stations used in the regression analyses.

\begin{tabular}{|c|c|c|c|}
\hline $\begin{array}{l}\text { Range in mean annual } \\
\text { precipitation } \\
\text { (inches) }\end{array}$ & & \multicolumn{2}{|c|}{$\begin{array}{l}\text { Number of stations } \\
\text { in analyses }\end{array}$} \\
\hline $\begin{array}{l}49-50 \\
51-52 \\
53-54 \\
55-56 \\
57-58 \\
59-60 \\
61-62 \\
63-64 \\
65-66 \\
67-68\end{array}$ & & $\begin{array}{r}6 \\
34 \\
42 \\
8 \\
10 \\
1 \\
1 \\
3 \\
2 \\
2\end{array}$ & $\begin{array}{r}6 \\
27 \\
39 \\
7 \\
8 \\
1 \\
1 \\
3 \\
2 \\
2\end{array}$ \\
\hline & Total stations ... & 109 & 96 \\
\hline
\end{tabular}

In Alabama the most widely used low-flow data are the $7 Q_{10}$. Thus, the regression analyses were first performed on the $7 Q_{10}$ low flow. Analyses for the $7 Q_{2}$ were performed after completion of the analyses for $7 Q_{10}$. Estimating equations derived from the regression analyses are of the same general form for both $7 Q_{2}$ and $7 Q_{10}$ low flow. The regression constant and coefficients are different for the two equations.

The first three regression analyses for $7 Q_{10}$ included 127 continuous record gaging stations. Nineteen of those stations had $7 Q_{10}$ of zero and 7 stations had $7 Q_{10}$ less than $0.1 \mathrm{ft}^{3} / \mathrm{s}$. The zero low-flow stations were assigned discharge values of $0.01 \mathrm{ft}^{3} / \mathrm{s}$ for analyses purposes. The assigned values for the 19 stations resulted in an excessive error of estimate. The 19 stations with zero $7 Q_{10}$ and the 7 stations with $7 Q_{10}$ less than $0.1 \mathrm{ft}^{3} / \mathrm{s}$ were deleted from each successive regression analysis. Deletion of the 26 stations resulted in an error of estimate of about one-half the error using all 127 stations. Estimates of low flow less than $0.3 \mathrm{ft}^{3} / \mathrm{s}$ for $7 Q_{2}$ and less than 0.1 for $7 Q_{10}$ were deleted from the regression analyses.

During the regression analyses different values were subtracted from the streamflow-recession index and from mean annual precipitation. The values were subtracted to reduce exponents of variables included in the equation and to increase the equation constant. The values subtracted from the streamflow-recession index were 10,15, 18, and 30. 
Values, in increments of 5, subtracted from mean annual precipitation ranged from 20 to 45 . In the final regression equation a value of 30 is subtracted from the streamflow-recession index and from mean annual precipitation.

The value of 30 is related to recession rate and evapotranspiration in Alabama. The zero low-flow areas have a streamflow-recession index of 32 . Thus, a value of 30 is the feasible maximum that can be subtracted from the index because of logarithmic transformations used in the regression analyses. The values of 30 subtracted from mean annual precipitation represents the approximate amount, in inches, of precipitation that is lost each year by evapotranspiration. However, subtracting large values from the variables used in regression equations can affect the linearity of those equations.

The linearity of the $7 Q_{2}$ and $7 Q_{10}$ equations in this report was checked with graphical plots. The graphs include plots of regression residuals versus streamflow-recession index, residuals versus drainage area, and residuals versus mean annual precipitation. The group of plotting points on each graph apparently forms a straight line.

A partial analysis of the sensitivity of the regression equations to mean annual precipitation $(P)$ and streamflow-recession index $(G)$ was performed for one set of conditions for each variable. Results of sensitivity of the equations for $G$ equal 50,100 , and 200 are as follows:

$A=100 \mathrm{mi}^{2}$,

$P=50$ in., and

$G=50$, then a 10 percent error in $G$ results in 25 to 30 percent error in $7 Q_{2}$, and 30 to 35 percent error in $7 Q_{10}$;

for $G=100$, then a 10 percent error in $G$ results in about 15 percent error in $7 Q_{2}$, and about 20 percent error in $7 Q_{10}$; and

for $G=200$, then a 10 percent error in $G$ results in about 13 percent error in $7 Q_{2}$, and about 16 percent error in $7 Q_{10}$.

Results of sensitivity of the equations for $P$ equal 50, 55, and 60 are as follows:

$$
\begin{aligned}
& A=100 \mathrm{mi}^{2}, \\
& P=50 \mathrm{in} ., \text { and } \\
& G=100, \text { then an error of } 2 \text { inches in } P \text { results in about } 15 \text { percent } \\
& \quad \text { error in } 7 Q_{2}, \text { and about } 17 \text { percent error in } 7 Q_{10} ;
\end{aligned}
$$

for $P=55$, then an error of 2 inches in $P$ results in about 12 percent error in $7 Q_{2}$, and about 13 percent error in $7 Q_{10}$; and for $P=60$, then an error of 2 inches in $P$ results in about 10 percent error in $7 Q_{2}$, and 11 percent error in $7 Q_{10}$.

The sensitivity analysis indicates the stability of each equation improves as the values of the variables $G$ and $P$ increase. 


\section{SUMMARY}

Regression equations derived from continuous-streamflow data, streamflow-recession index, drainage area, and mean annual precipitation can be used to estimate $7 Q_{2}$ and $7 Q_{10}$ low flow for natural flow for ungaged streams in Alabama. The equations apply statewide. Estimates of low flow are very important for waste disposal regulation. The permissible rate of waste disposal is based on the $7 Q_{10}$ low flow.

A unique method was developed to account for the effects of geology on low flow. The relative effects of different rock types on low flow were defined by the rate of streamflow recession. The rate of recession is controlled by the hydraulic characteristics of aquifers within the geologic framework. The streamflow-recession index, in days per log cycle, was used in the analysis of data for this report. These indexes for each gaging station used in the analyses were related to a generalized geologic map of the State.

\section{REFERENCES CITED}

Daniel, J. F., 1976, Estimating ground-water evapotranspiration from streamflow records, in Water Resources Research: American Geophysical Union, v. 12, no. 3, p. $360-364$.

Hayes, E. C., 1978, 7-day low flows and flow duration of Alabama streams through 1973: Alabama Geological Survey Bulletin 113, 163 p.

Peirce, L. B., 1959, Low-flow and flow-duration data for Alabama streams: Alabama Water Improvement Commission Report.

1967, 7-day low flows and flow duration of Alabama streams: Alabama Geological Survey Bulletin 87, part A, 114 p.

Riggs, H. C., 1964, The base-flow recession curve as an indicator of ground water: International Association of Scientific Hydrology Publication 63, p. 352-363.

Rorabaugh, M. I., Simons, W. D., Garrett, A. A., and McMurtrey, R. G., 1966, Exploration of methods of relating ground water to surface water-Columbia River basin first phase, with a section on direct computation of ground-water outflow by electric analog by B. J. Bermes: U.S. Geological Survey Open-file report, $124 \mathrm{p}$.

Thomas, M. P., and Cervione, M. A., Jr., 1970, A proposed streamflow data program for Connecticut: Connecticut Water Resources Commission, Bulletin 23.

Trainer, F. W., and Watkins, F. A., Jr., 1974, Use of base-runoff recession curves to determine areal transmissivities in the upper Potomac River basin: U.S. Geological Survey Journal of Reserarch, v. 2, no. 1, p. 125-131.

U.S. Geological Survey, 1932, Geologic map of the United States.

U.S. National Weather Service, 1957, Climates of the States, v. 1-Eastern States. 
SUPPLEMENTS A AND B 


\section{SUPPLEMENT A}

\section{ESTIMATES OF LOW FLOW FOR UNGAGED SITES}

The following computations demonstrate the application of regression equations for estimating low flow in ungaged streams in Alabama. For the first example, assume a stream site where the entire basin has a single streamflow-recession index. Assume a $42-\mathrm{mi}^{2}$ basin lying within a region having an index of 50 and a mean annual precipitation of 53 inches. Estimates of $7 Q_{2}$ and $7 Q_{10}$ are computed with the regression equations in the following manner.

$$
\begin{aligned}
& 7 Q_{2}=0.24 \times 10^{-4}(G-30)^{1.07}(A)^{0.94}(P-30)^{1.51} \\
& 7 Q_{2}=0.24 \times 10^{-4}(50-30)^{1.07}(42)^{0.94}(53-30)^{1.51} \\
& 7 Q_{2}=0.24 \times 10^{-4}(20)^{1.07}(42)^{0.94}(23)^{1.51} \\
& 7 Q_{2}=2.3 \mathrm{ft}^{3} / \mathrm{s} \\
& 7 Q_{10}=0.15 \times 10^{-5}(G-30)^{1.35}(A)^{1.05}(P-30)^{1.64} \\
& 7 Q_{10}=0.15 \times 10^{-5}(50-30)^{1.35}(42)^{1.05}(53-30)^{1.64} \\
& 7 Q_{10}=0.15 \times 10^{-5}(20)^{1.35}(42)^{1.05}(23)^{1.64} \\
& 7 Q_{10}=0.7 \mathrm{ft}^{3} / \mathrm{s}
\end{aligned}
$$

For the second example, assume a stream site where the stream is draining areas having two streamflow-recession indexes and 70 percent of the basin is in an area with an index of 50 , and 30 percent of the basin has an index of 100 . The entire basin has a drainage area of $75 \mathrm{mi}^{2}$ and mean annual precipitation for the site is 55 inches. The estimating equations are used for the entire basin using each of the two streamflowrecession indexes, then a weighted average discharge is computed based on the percentage of the basin draining each area. Estimates of $7 Q_{2}$ and $7 Q_{10}$ are computed with the regression equations in the following manner. First, assume the entire basin is draining an area having a streamflow-recession index of 50 .

$$
\begin{aligned}
& 7 Q_{2}=0.24 \times 10^{-4}(G-30)^{1.07}(A)^{0.94}(P-30)^{1.51} \\
& 7 Q_{2}=0.24 \times 10^{-4}(50-30)^{1}{ }^{107}(75)^{0}{ }^{94}(55-30)^{151} \\
& 7 Q_{2}=0.24 \times 10^{-4}(20)^{1}{ }^{17}(75)^{0}{ }^{94}(25)^{151} \\
& 7 Q_{2}=4.4 \mathrm{ft}^{3} / \mathrm{s}
\end{aligned}
$$

Then assume the entire basin is draining an area having a streamflowrecession index of 100 .

$$
\begin{aligned}
& 7 Q_{2}=0.24 \times 10^{-4}(G-30)^{1.07}(A)^{0.94}(P-30)^{1.51} \\
& 7 Q_{2}=0.24 \times 10^{-4}(100-30)^{107}(75)^{094}(55-30)^{151} \\
& 7 Q_{2}=0.24 \times 10^{-4}(70)^{107}(75)^{094}(25)^{151} \\
& 7 Q_{2}=17 \mathrm{ft}^{3} / \mathrm{s}
\end{aligned}
$$

The estimated discharge of $4.4 \mathrm{ft}^{3} / \mathrm{s}$ and $17 \mathrm{ft}^{3} / \mathrm{s}$ for $7 Q_{2}$ are weighted based on the 70 and 30 percent of the basin draining areas of each streamflow-recession index. 
$4.4 \mathrm{ft}^{3} / \mathrm{s}(.7)=3.1 \mathrm{ft}^{3} / \mathrm{s}$

$17 \mathrm{ft}^{3} / \mathrm{s}(.3)=5.1 \mathrm{ft}^{3} / \mathrm{s}$

Weighted average discharge $=8.2 \mathrm{ft}^{3} / \mathrm{s}$ for $7 Q_{2}$

The $8.2 \mathrm{ft}^{3} / \mathrm{s}$ is the estimated $7 Q_{2}$ discharge for the stream site in the second example.

The same procedure applies for estimating the $7 Q_{10}$ discharge. First, assume the entire basin is draining an area having a streamflowrecession index of 50 .

$$
\begin{aligned}
& 7 Q_{10}=0.15 \times 10^{-5}(G-30)^{1{ }^{35}}(A)^{1{ }^{05}}(P-30)^{164} \\
& 7 Q_{10}=0.15 \times 10^{-5}(50-30)^{1{ }^{35}}(75)^{1{ }^{05}}(55-30)^{164} \\
& 7 Q_{10}=0.15 \times 10^{-5}(20)^{1{ }^{35}}(75)^{{ }^{105}(25)^{164}} \\
& 7 Q_{10}=1.6 \mathrm{ft}^{3} / \mathrm{s}
\end{aligned}
$$

Then assume the entire basin is draining an area having a streamflowrecession index of 100 .

$$
\begin{aligned}
& 7 Q_{10}=0.15 \times 10^{-5}(G-30)^{135}(A)^{1{ }^{05}}(P-30)^{164} \\
& 7 Q_{10}=0.15 \times 10^{-5}(100-30)^{135}(75)^{1{ }^{05}}(55-30)^{164} \\
& 7 Q_{10}=0.15 \times 10^{-5}(70)^{135}(75)^{1{ }^{05}}(25)^{164} \\
& 7 Q_{10}=8.5 \mathrm{ft}^{3} / \mathrm{s}
\end{aligned}
$$

The estimated discharges of $1.6 \mathrm{ft}^{3} / \mathrm{s}$ and $8.5 \mathrm{ft}^{3} / \mathrm{s}$ for $7 Q_{10}$ are averaged based on the 70 and 30 percent of the basin draining each area.

$1.6 \mathrm{ft}^{3} / \mathrm{s}(.7)=1.1 \mathrm{ft}^{3} / \mathrm{s}$

$8.5 \mathrm{ft}^{3} / \mathrm{s}(.3)=2.6 \mathrm{ft}^{3} / \mathrm{s}$

Weighted average discharge $=3.7 \mathrm{ft}^{3} / \mathrm{s}$ for $7 Q_{10}$ The $3.7 \mathrm{ft}^{3} / \mathrm{s}$ is the estimated $7 Q_{10}$ discharge for the stream site in the second example.

For the third example, assume a stream site where the stream is draining areas having three streamflow-recession indexes and 50 percent of the basin is in an area with an index of 65,30 percent of the basin is in an area with an index of 100 , and 20 percent of the basin is in an area with an index of 50 . Drainage area is $125 \mathrm{mi}^{2}$ and mean annual precipitation is 52 inches. The estimating equations are used for the entire basin using each of the three streamflow-recession indexes, then a weighted average discharge is computed based on the percent of the basin in each area. Estimates of $7 Q_{2}$ and $7 Q_{10}$ are computed with regression equations in the following manner. First, assume the entire basin has a streamflow-recession index of 65 .

$$
\begin{aligned}
& 7 Q_{2}=0.24 \times 10^{-4}(G-30)^{1{ }^{07}}(A)^{0}{ }^{94}(P-30)^{151} \\
& 7 Q_{2}=0.24 \times 10^{-4}(65-30)^{107}(125)^{094}(52-30)^{151} \\
& 7 Q_{2}=0.24 \times 10^{-4}(35)^{107}(125)^{094}(22)^{151} \\
& 7 Q_{2}=11 \mathrm{ft}^{3} / \mathrm{s}
\end{aligned}
$$

Next, assume the entire basin has a streamflow-recession index of 100 .

$$
\begin{aligned}
& 7 Q_{2}=0.24 \times 10^{-4}(G-30)^{107}(A)^{094}(P-30)^{151} . \\
& 7 Q_{2}=0.24 \times 10^{-4}(100-30)^{10}(125)^{094}(52-30)^{151}
\end{aligned}
$$




$$
\begin{aligned}
& 7 Q_{2}=0.24 \times 10^{-4}(70)^{107}(125)^{094}(22)^{151} \\
& 7 Q_{2}=23 \mathrm{ft}^{3 / 3} / \mathrm{s}
\end{aligned}
$$

Finally assume the entire basin has a streamflow-recession index of 50 .

$$
\begin{aligned}
& 7 Q_{2}=0.24 \times 10^{-4}(G-30)^{1{ }^{17}}(A)^{0}{ }^{94}(P-30)^{151} \\
& 7 Q_{2}=0.24 \times 10^{-4}(50-30)^{107}(125)^{0^{94}}(52-30)^{151} \\
& 7 Q_{2}=0.24 \times 10^{-1}(20)^{1{ }^{07}}(125)^{0}{ }^{94}(22)^{151} \\
& 7 Q_{2}=5.9 \mathrm{ft}^{3} / \mathrm{s}
\end{aligned}
$$

The estimated discharges of $11 \mathrm{ft}^{3} / \mathrm{s}, 23 \mathrm{ft}^{3} / \mathrm{s}$, and $5.9 \mathrm{ft}^{3} / \mathrm{s}$ for $7 Q_{2}$ are weighted based on 50, 30, and 20 percent of the basin draining areas of each streamflow-recession index.

$11 \mathrm{ft}^{3} / \mathrm{s}(.5)=5.5 \mathrm{ft}^{3} / \mathrm{s}$

$23 \mathrm{ft}^{3} / \mathrm{s}(.3)=6.9 \mathrm{ft}^{3} / \mathrm{s}$

$5.9 \mathrm{ft}^{3} / \mathrm{s}(.2)=1.2 \mathrm{ft}^{3} / \mathrm{s}$

Weighted average discharge $=13.6 \mathrm{ft}^{3} / \mathrm{s}$ for $7 Q_{2}$

The $13.6 \mathrm{ft}^{3} / \mathrm{s}$ is rounded to the nearest whole number, thus, $14 \mathrm{ft}^{3} / \mathrm{s}$ is the estimated $7 Q_{2}$ for the stream site in the third example.

The same procedure applies for estimating $7 Q_{10}$ for the stream site draining three areas with different streamflow-recession indexes. The equation for estimating $7 Q_{10}$ is used for each index area and a weighted average discharge computed based on the percent of the basin draining each area. The estimated $7 Q_{10}$ for the stream site in the third example is $7.0 \mathrm{ft}^{3} / \mathrm{s}$. 


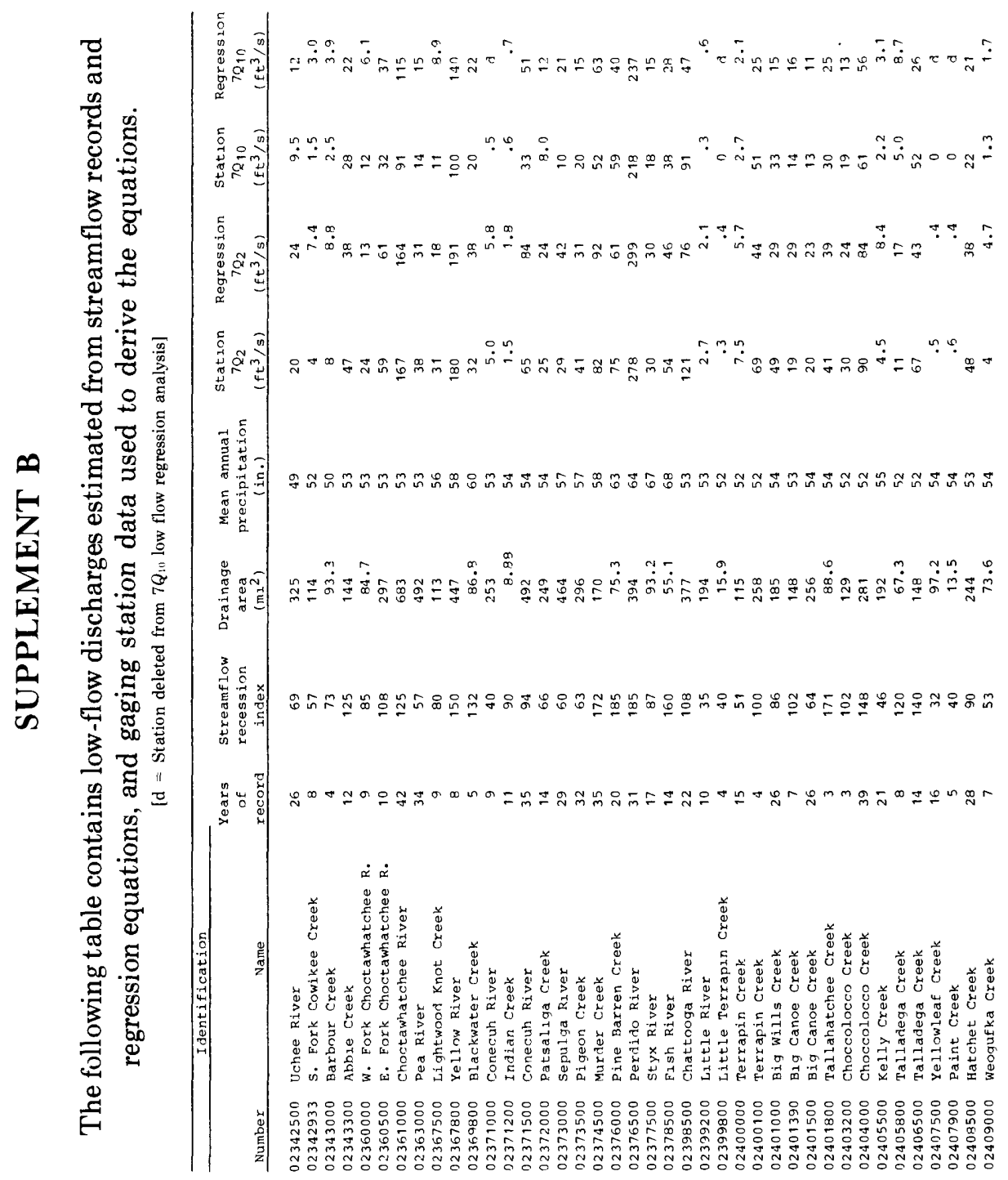




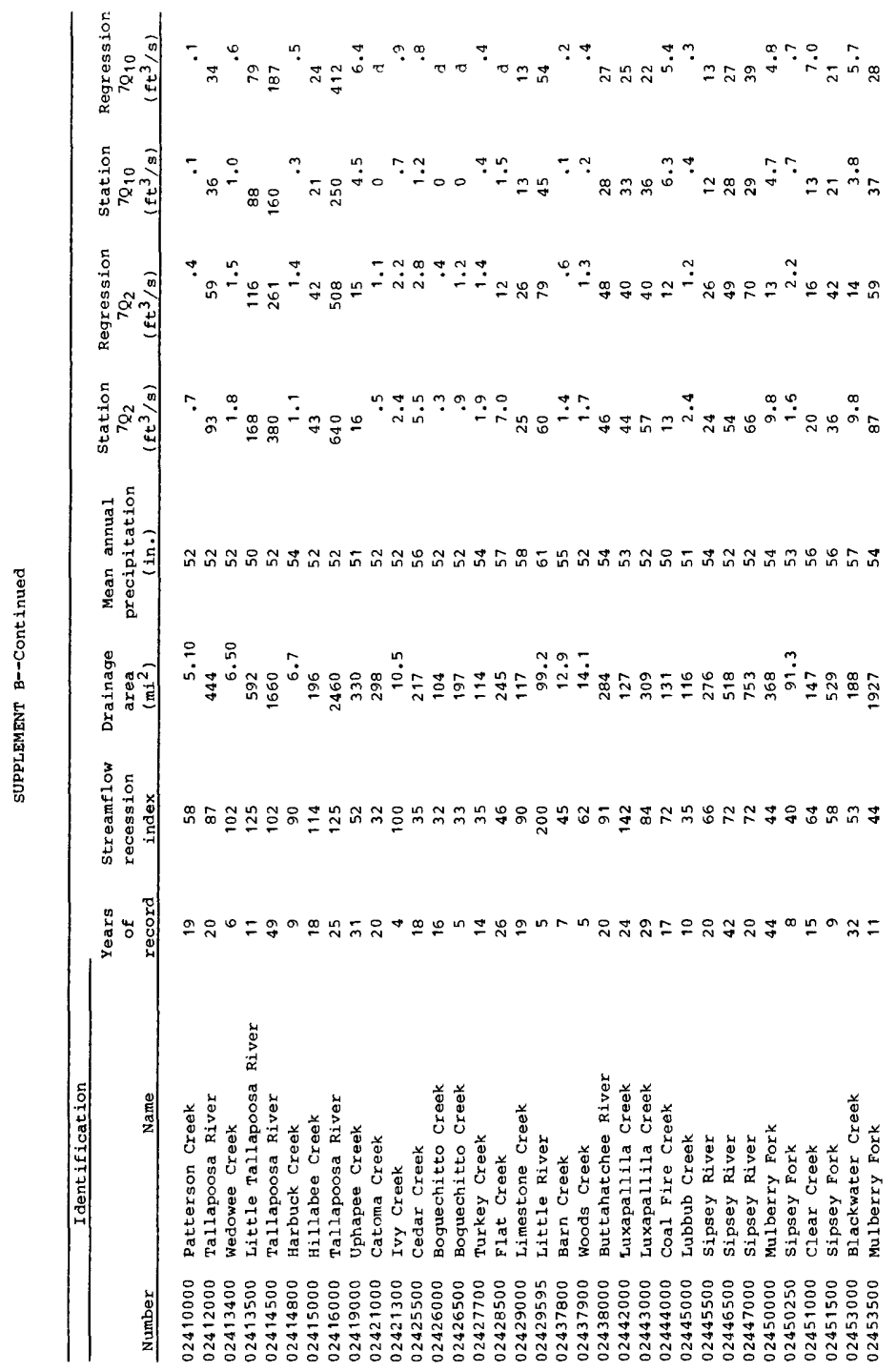




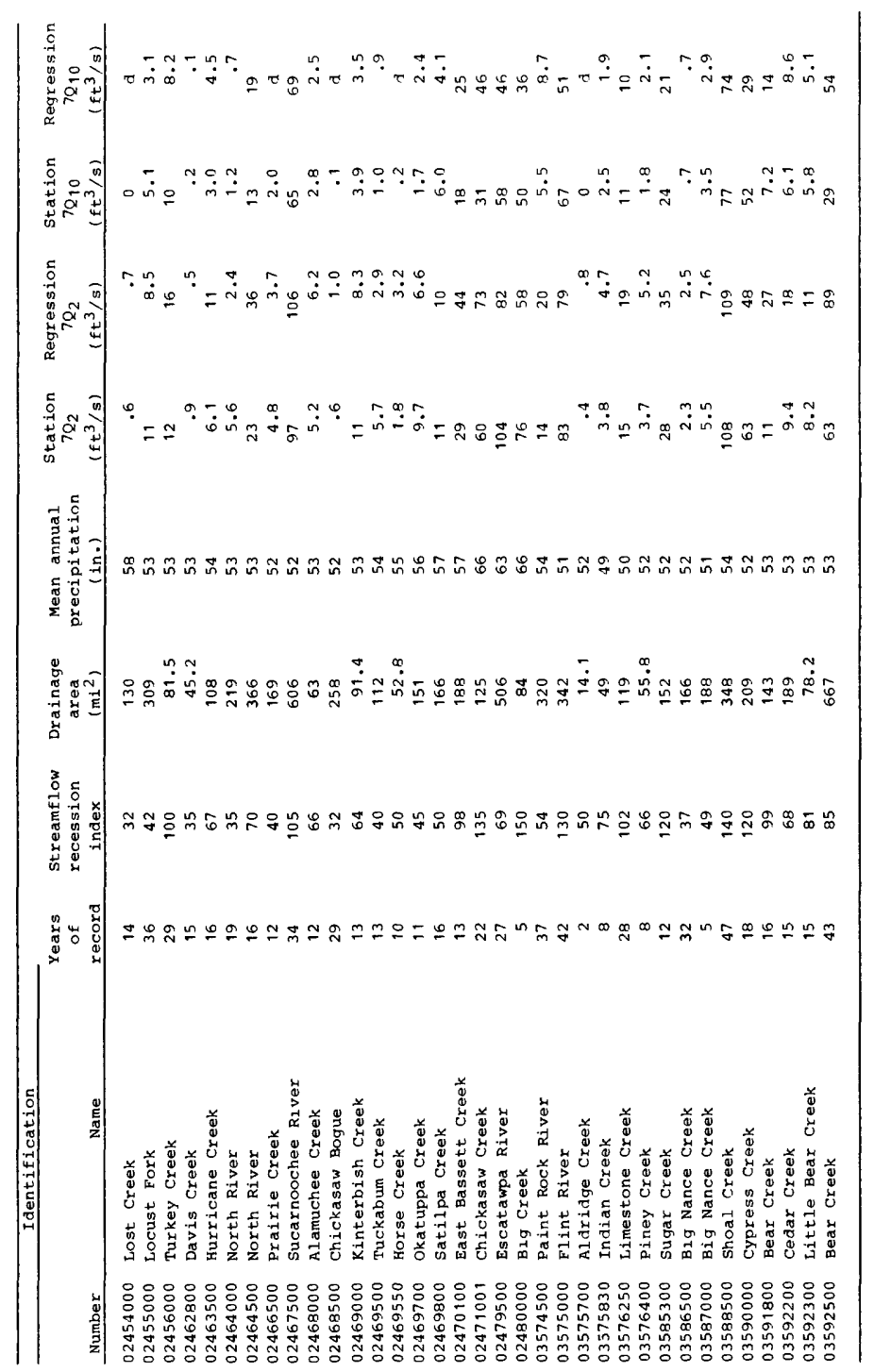

